\title{
California agritourism operations and their economic potential are growing
}

\author{
by Ellen Rilla, Shermain D. Hardesty, Christy \\ Getz and Holly George
}

More than 2.4 million visitors participated in agritourism at California farms and ranches in 2008. They stayed at guest ranches in the foothills, picked peaches in the Sacramento Valley, played in corn mazes up and down the state, shopped at on-farm produce stands along the coast, held weddings in fields and vineyards from coast to mountains, and experienced myriad other agriculture-related tourism activities. The UC Small Farm Program conducted the first statewide economic survey of California agritourism operators to better understand their goals, needs and economic outlook. University researchers from several other states provided input and sample data from state surveys conducted between 2000 and 2007. This information will help to target outreach and address current and emerging challenges.

\section{7 he pressures of urbanization and 1 shrinking profits have led Cali-} fornia farmers to seek alternative approaches for maintaining profitable agricultural enterprises. "Agritourism" includes any income-generating activity conducted on a working farm or ranch for the enjoyment and education of visitors. It includes the interpretation of the natural, cultural, historical and environmental assets of the land and people working on it (George and Rilla 2008).

Agritourism is growing nationwide as farm operators in many states offer activities as a way to diversify and increase their profits (Brown and Reeder 2007). In 2002, the U.S. Department of Agriculture (USDA) Census of Agriculture began collecting

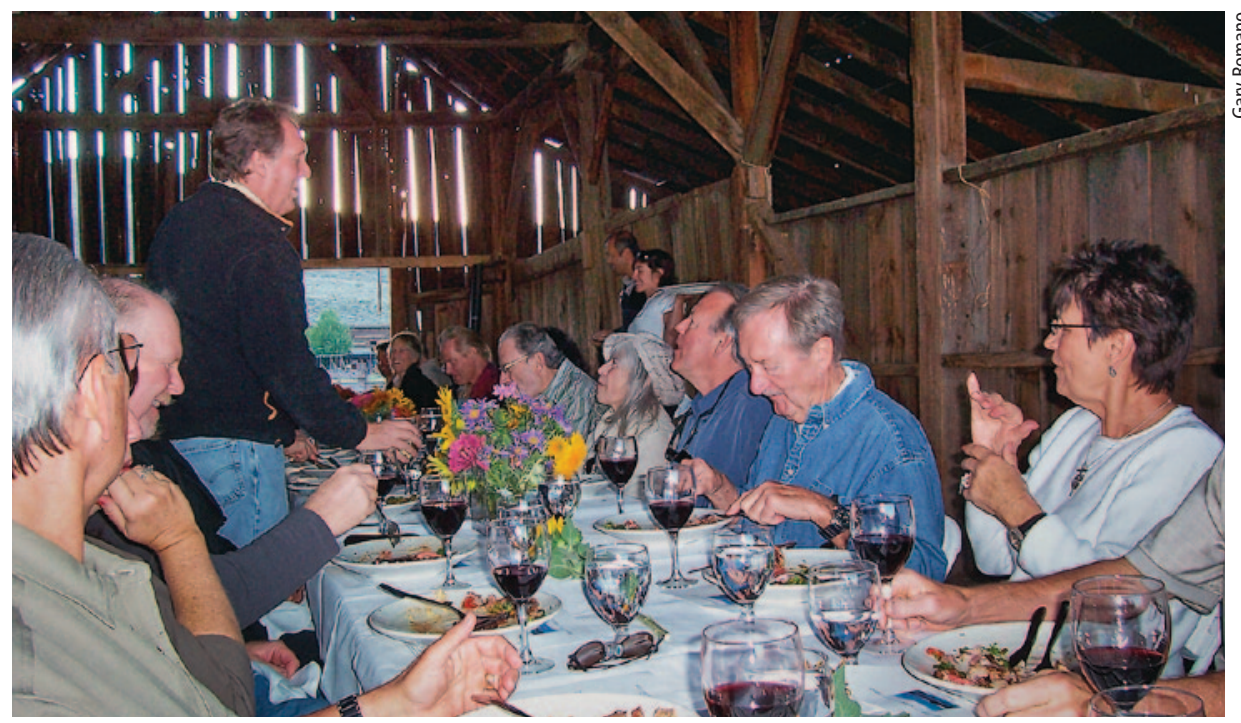

Many California growers offer the public "agritourism" opportunities as a way of improving their farm's visibility and profitability. Above, visitors enjoy a gourmet "Dinner in the Barn" at the Romano Family's Sierra Valley Farm in Plumas County.

agritourism statistics. In 2007, 685

California farms reported a total of $\$ 35$ million in revenue related to agritourism (USDA 2009). However, the USDA definition of agritourism is extremely limited; it includes some recreational or educational experiences occurring on farms, such as hay rides and pumpkin patches, but does not explicitly include other major on-farm activities such as festivals, accommodations or direct sales of products.

The USDA Economic Research Service's Agricultural Resource Management Survey (ARMS) (USDA 2004) was used as a data set for the agency's 2007 report on farm-based recreation (Brown and Reeder 2007). The authors used the terms "farm-based recreation" and "agritourism" interchangeably but acknowledged that because ARMS data on farm-based recreation does not describe hospitality services and direct sales of on-farm products, their estimates are conservative. (Both the Census of Agriculture and ARMS data would be more useful if the USDA developed and applied a standardized definition of agritourism activities.)

Other national data sources also support the economic development potential of agritourism. Nearly twothirds of all U.S. adults (87 million) have taken a trip to a rural destination within the last 3 years (Miller 2005). USDA estimates that more than 82 million people, including approximately 20 million youth and children under age 16, visited farms during a 1-year period between 2000 and 2001. U.S. Fish and Wildlife Service reports indicate that in 2006 more than 6.2 million wildlife and nature tourists spent more than $\$ 7.8$ billion in California (Leonard 2008).

\section{Building a survey}

Nationally, few systematic statewide studies have evaluated the agritourism sector (Ryan et al. 2006; Bruch and Holland 2004; Kuehn 2002), and none have been conducted in California (with the exception of the California wine industry, which attributes $\$ 2$ billion to tourism-related sales [The Wine Institute 2006]).

To help fill this void, chairs of the UC Cooperative Extension (UCCE) Agricultural Tourism Workgroup convened a survey team, which included the director of the UC Small Farm Program, academics and graduate students. The team members identified key areas that would enhance a general understanding of California's agritourism sector and improve the quality of UCCE outreach and extension. The 
survey contained fill-in-the-blank and multiple-choice questions about location, products and services, motivation, advertising, management, profitability, visitation and future plans. It also included open-ended questions, giving agritourism operators the opportunity to share issues, concerns, challenges and successes. The survey asked respondents to answer financial and management questions based on their experiences in 2008.

Historically, one barrier to conducting a systematic analysis of the agritourism sector in California has been the lack of a comprehensive database of farms engaged in agritourism. The survey team built a database from addresses contributed by UCCE academics, lists of agritourism operators and workshop participants, addresses from local marketing campaigns, and other relevant agency lists and databases. The new database also included small, family-owned wineries (which produce fewer than 10,000 cases annually) that were engaged in non-wine-related agritourism activities such as on-farm sales of jams, herbs, olive oil, grassfed beef and other value-added products.

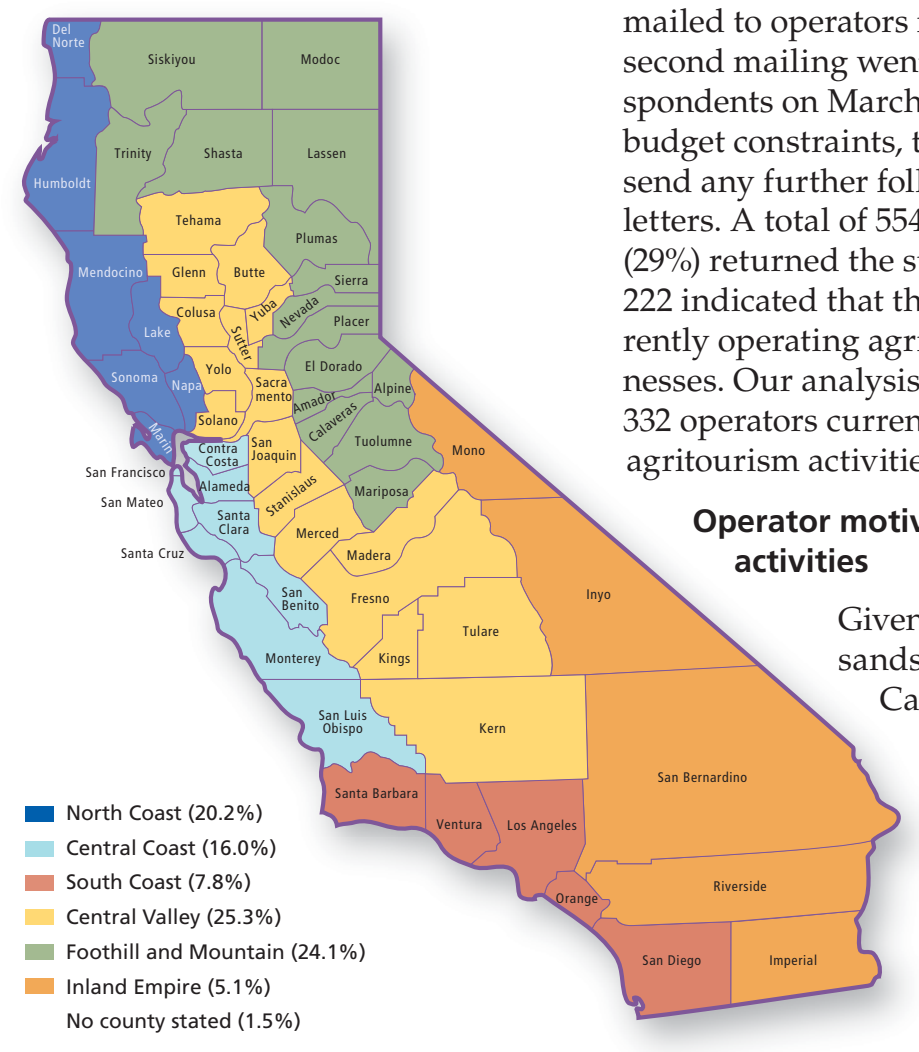

Fig. 1. Responses to agritourism survey by California region.

Despite our attempts to be comprehensive, the resulting database of 1,940 farm businesses most likely does not include all agritourism operators in the state. As such, our resulting sample is not completely random, and therefore we are not able to generalize our findings to the entire agritourism sector. The total number of visitors is likely orders of magnitude larger, especially when compared with other visitor figures reported in less populated states. Nonetheless, our findings provide valuable insights into the political, social and economic context, and characteristics of agritourism in California.

After developing and piloting the survey, the team worked closely with the UC Small Farm Program to implement it. On Jan. 10, 2009, the survey was mailed to operators in the database. A second mailing went out to all nonrespondents on March 10, 2009. Due to budget constraints, the team did not send any further follow-up reminder letters. A total of 554 farm businesses (29\%) returned the survey, of which 222 indicated that they were not currently operating agritourism businesses. Our analysis is based on the 32 operators currently participating in activities.

Operator motivation and Given the tens of thousands of small farms in California and the competitive pressure on small farmers due to agricultural restructuring, we hypothesized that the financial need to diversify would be a key factor in motivating farm and ranch operators to open up to visitors. Indeed, $75 \%$ of our respondents cited the need to increase profitability as a reason for entering into agritourism. Other economic reasons included "to market farm products" (62\%) and "to provide an employment opportunity for family members" (22\%).

Profit and employment opportunities were not the only reasons cited. Three-quarters of those who entered the agritourism sector for financial or employment reasons also did so because they "wanted to educate visitors," "enjoyed working with people" or wanted to provide "outreach to the community." Only 15\% started an agritourism venture solely for outreach or educational purposes, with no financial motivation. These findings support other research suggesting that a complex set of economic and social factors motivate farmers to pursue agritourism (Mace 2005).

Operator characteristics. Almost half (43\%) of the agritourism operators surveyed had been in the sector less than 10 years. Respondents were grouped into six regions in California, with the Central Valley region having the most operations (25\%) and the Foothill and Mountain region close behind (24\%) (fig. 1).

Agritourism activities. Agritourism operators in California were engaged 
in a wide range of activities, offering direct sales (78\%), tours or lectures (81\%), demonstrations, lessons or participant experiences (69\%) and special event facilities (51\%) (table 1). In general, agritourism operators made more money from direct sales of agricultural products (45\% on average of all agritourism gross income) than from other activities. The most common directsales activity was selling produce, nuts or flowers at a farm stand (38\%).

The most common agritourism activity $(51 \%)$ was hosting school field trips, with only $17 \%$ charging a fee. With the exception of weddings, overnight stays, horse or wagon rides, and fishing or hunting, less than half of agritourism operators participating in each service activity charged a fee, underscoring the public-service, educational and marketing/outreach nature of these activities.

While the low percentage of operators charging fees for school field trips is not surprising given the publicservice nature of the activity, the fact that many other services are provided for free is puzzling. Although service activities such as tours already have a strong marketing angle related to direct sales, other activities such as cultural festivals or farm demonstrations could potentially serve as a source of income. One operator commented, "We have not developed agritourism into a moneymaking operation. Most visitors are nonpaying customers. We are moving in the direction of having paid activities and stays."

\section{Promotional strategies}

There is no single formula for marketing success in agritourism (Chesnutt 2007). Operators estimated that on average $88 \%$ of their visitors in 2008 were from California, with $50 \%$ coming from the same county. This finding is consistent with the state tourism and travel commission figure that $85 \%$ of visitors were from in-state in 2008 (CTTC 2008). On average, only about $3 \%$ of visitors were from Canada or other countries.

More than half (51\%) of the businesses responding to the survey had fewer than 500 visitors in 2008, while $12 \%$ hosted more than 20,000 visitors. October was the highest volume month, with activities such as pumpkin patches, apple picking, winery tastings and tours, corn mazes, harvest festivals and end-of-summer fruit and vegetable purchases.

Types of promotion. Word of mouth was the leading form of promotion used by respondents (97\%) to reach customers (fig. 2). Signs outside of businesses $(81 \%)$, business cards/brochures $(76 \%)$ and websites $(78 \%)$, along with listings in regional guides (74\%), were the next most popular forms of marketing. The next tier of marketing included

\begin{tabular}{|c|c|c|}
\hline & Offered & Offered for a fee \\
\hline & $\ldots \ldots \ldots \ldots$ & $\% \ldots \ldots \ldots \ldots$ \\
\hline Direct sales & 78.3 & \\
\hline Farm stand with fresh fruit, vegetables, herbs or flowers & 37.6 & \\
\hline Farm stand with farmstead items (pies, cider, soaps, etc.) & 17.0 & \\
\hline U-pick fruit, vegetable, herb or flower operation & 22.7 & \\
\hline Christmas tree sales (U-cut or retail) & 9.7 & \\
\hline Pumpkin patches & 17.6 & \\
\hline Corn mazes & 7.0 & \\
\hline Animal meat or cheese sales & 9.1 & \\
\hline Vineyard, winery & 21.5 & \\
\hline Other sales & 10.9 & \\
\hline Tours or lectures & 81.0 & \\
\hline School field trips & 51.1 & 17.2 \\
\hline Traditional farm or ranch operation and buildings & 40.8 & 9.4 \\
\hline Seasonal activities (calving, shearing, planting, harvesting, etc.) & 32.3 & 5.4 \\
\hline Scenic attractions: Unique features of property & 30.5 & 7.6 \\
\hline Small-animal demonstrations & 13.0 & 2.7 \\
\hline Historic buildings or farm equipment & 18.7 & 3.6 \\
\hline Seasonal sites (spring blooms, fall foliage, winter snow, etc.) & 18.7 & 2.4 \\
\hline Forest ecology or native plants & 14.8 & 2.4 \\
\hline Demonstrations, lessons, participant experiences & 69.3 & \\
\hline Classes, workshops (cheese making, felting, cider production, etc.) & 35.8 & 13.6 \\
\hline Cattle drives, branding, roping, rodeo, etc. & 2.7 & 1.5 \\
\hline Horseback riding, wagon or sleigh rides & 8.8 & 4.8 \\
\hline Barn raising, pond or fence construction & 3.3 & 1.5 \\
\hline Gardening: Plant selection, planting, harvesting, etc. & 23.0 & 3.6 \\
\hline Cooking, food tasting or wine/beer pairing & 27.5 & 12.1 \\
\hline Land restoration or habitat improvements & 11.8 & 2.4 \\
\hline Fishing or hunting & 10.9 & 6.6 \\
\hline Special event facilities & 50.6 & \\
\hline Weddings, family reunions, retreats, etc. & 32.9 & 22.4 \\
\hline Farm stays (people stay in home or another farmhouse) & 15.1 & 8.8 \\
\hline Camping or RV accommodations & 10.6 & 3.9 \\
\hline Cabins or overnight facilities not in home or another farmhouse & 11.2 & 7.6 \\
\hline Cultural festivals & 10.9 & 5.1 \\
\hline Wildlife or migratory bird festivals & 3.0 & 0.6 \\
\hline Horse activities and events: Cuttings, rodeos & 5.7 & 2.4 \\
\hline Dog trials & 3.3 & 2.7 \\
\hline Youth camps & 6.6 & 4.8 \\
\hline
\end{tabular}


leading impediments to farmers and ranchers who wanted to expand their operations to include agritourism (fig. 4). Comments from respondents, regardless of region, indicated that they were frustrated and overwhelmed with their county's policies and procedures, and the expenses related to initiating or expanding an agritourism enterprise on their farm or ranch.

Twenty-nine percent $(n=97)$ indicated that they had acquired a use permit from their county for an agritourism operation. Among these respondents, 69\% responded negatively (expensive, difficult, slow) to questions about the permitting process, while $31 \%$ responded with positive or neutral comments (workable, not complicated, officials very cooperative). These comments echo the frustration expressed by operators who participated in a 2002 survey regarding the permitting process for agritourism in 10 California counties (Keith et al. 2003).

Only $24 \%$ of the respondents had a business plan for their entire farm or ranch, but of those who did, 91\% included their agritourism operation. Those with business plans for their entire farm were about twice as likely as those with no business plans to have agritourism incomes above $\$ 100,000$.

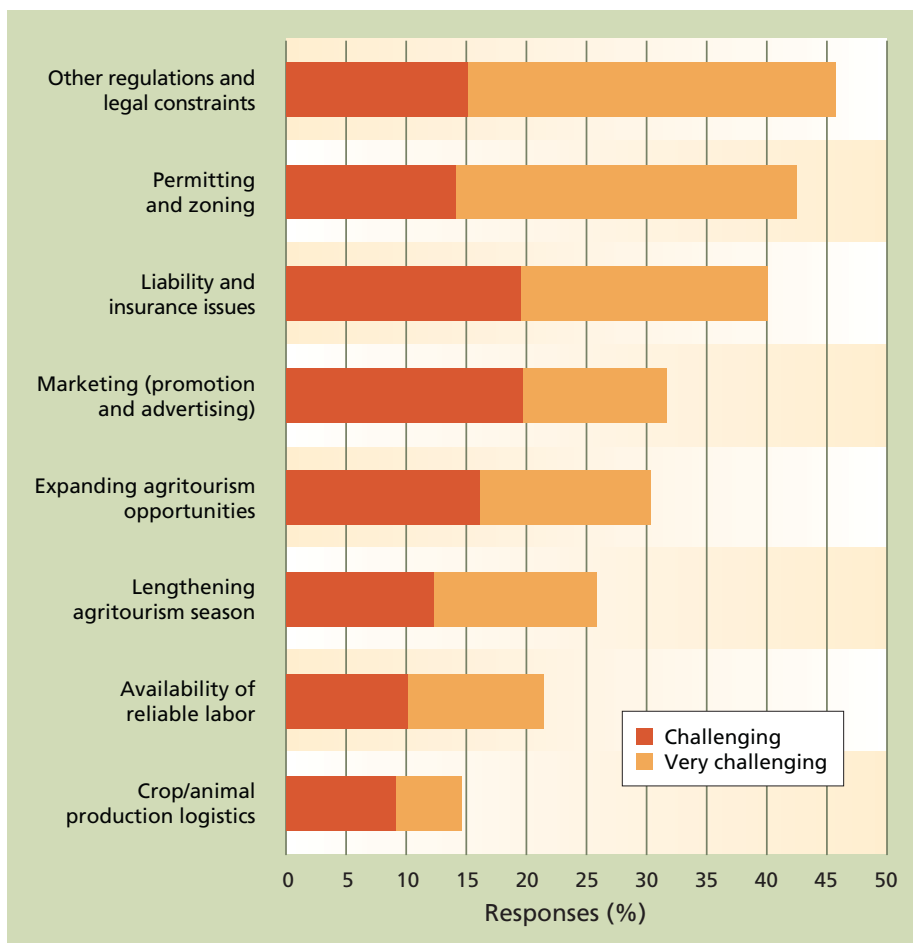

Fig. 4. Major challenges rated 4 or 5 by California agritourism operators, on a scale of 1 (not a problem) to 5 (very challenging).

\begin{tabular}{|c|c|c|c|c|c|c|c|}
\hline \multirow[b]{2}{*}{ Gross revenue } & \multicolumn{6}{|c|}{ Region } & \multirow[b]{2}{*}{ Total } \\
\hline & $\begin{array}{l}\text { North } \\
\text { Coast }\end{array}$ & $\begin{array}{c}\text { Central } \\
\text { Coast }\end{array}$ & $\begin{array}{l}\text { South } \\
\text { Coast }\end{array}$ & $\begin{array}{l}\text { Central } \\
\text { Valley }\end{array}$ & $\begin{array}{c}\text { Foothill } \\
\text { and } \\
\text { Mountain }\end{array}$ & $\begin{array}{l}\text { Inland } \\
\text { Empire }\end{array}$ & \\
\hline \multicolumn{8}{|c|}{ 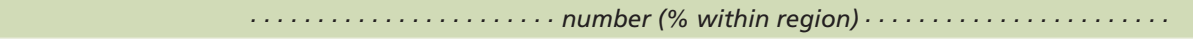 } \\
\hline Less than $\$ 1,000$ & $16(31.4)$ & $10(22.2)$ & $2(8.7)$ & $8(12.7)$ & $21(33.3)$ & $1(6.7)$ & $58(22.3)$ \\
\hline$\$ 1,000-\$ 4,999$ & $8(15.7)$ & $7(15.6)$ & $2(8.7)$ & $14(22.2)$ & $13(20.6)$ & $1(6.7)$ & 45 (17.3) \\
\hline$\$ 5,000-\$ 9,999$ & 7 (13.7) & $0(0)$ & $2(8.7)$ & $3(4.8)$ & $7(11.1)$ & $2(13.3)$ & $21(8.1)$ \\
\hline$\$ 10,000-\$ 24,999$ & $4(7.8)$ & $6(13.3)$ & $4(17.4)$ & $4(6.3)$ & $6(9.5)$ & $1(6.7)$ & $25(9.6)$ \\
\hline$\$ 25,000-\$ 49,999$ & $4(7.8)$ & $8(17.8)$ & $6(26.1)$ & $12(19.0)$ & $5(7.9)$ & $1(6.7)$ & 36 (13.8) \\
\hline$\$ 50,000-\$ 99,999$ & $4(7.8)$ & $4(8.9)$ & $2(8.7)$ & $7(11.1)$ & $2(3.2)$ & $1(6.7)$ & $20(7.7)$ \\
\hline$\$ 100,000$ or more & $8(15.7)$ & $10(22.2)$ & $5(21.7)$ & $15(23.8)$ & $9(14.3)$ & $8(53.3)$ & $55(21.2)$ \\
\hline Total number & 51 & 45 & 23 & 63 & 63 & 15 & 260 \\
\hline
\end{tabular}

When asked about liability insurance and other risk management practices, $87 \%$ reported having liability insurance, and $90 \%$ of the insured were covered for \$1 million or more. Several people commented about the cost of liability insurance and expressed concerns about being sued. Although most of the respondents carried insurance, operators rated liability and insurance issues as major challenges, along with permitting, zoning and other regulations and legal constraints.

Farmers and ranchers share the problems voiced by California agritourism operators across the nation. However, other states are moving forward on programs to help operators overcome challenges, and they may be useful models for California. For example, Colorado and Tennessee are appropriating funds for the promotion and development of agritourism, and Georgia and Missouri give tax benefits to agritourism operators. At least 19 states have enacted statutes that address agritourism, ranging from tax credits to zoning requirements to liability issues (Mirus 2009).

\section{Profitability of agritourism}

Although $14 \%$ of the survey respondents had annual revenues of $\$ 1,000,000$ or more, $68 \%$ fit the USDA definition of a small farm, having annual gross revenues of $\$ 250,000$ or less in 2008 . Almost half $(48 \%)$ of the operators reported less than $\$ 10,000$ in gross revenues from their agritourism operations in 2008, while $21 \%$ had revenues of $\$ 100,000$ or more (table 2).

While the number of Inland Empire respondents was relatively small, the region had a considerably higher proportion of operations with gross revenues of $\$ 50,000$ or more $(60 \%)$. Conversely, the North Coast (61\%) and Foothill and Mountain (65\%) regions had higher proportions of small agritourism operations with gross revenues under $\$ 10,000$. Differences in the proportion of operations within gross revenue categories among regions were statistically significant at the 0.05 level.

A primary activity was defined as one generating more than $50 \%$ of an operation's total agritourism revenue. The primary activities for which operators were most likely to have gross agritourism revenues of $\$ 50,000$ or more were corn maze/pumpkin patch (44\%), nature activities (43\%), retail sales of agricultural products (33\%) and events $(25 \%)$. Differences in the proportion of operations within gross revenue categories among regions were statistically significant at the 0.05 level (differences 
in observations across all categories were tested using the Pearson chisquared test).

Agritourism operators were asked to rate the profitability of their operation on a 7-point scale, with " 1 " indicating "not at all profitable" and "7" meaning "highly profitable." One-fourth considered their agritourism operations to be at least "fairly profitable" (rated 5 or higher), while $16 \%$ rated their operations as "not at all profitable." The mean profitability rating was 3.3. However, generating profit was not a direct objective for some agritourism operations. One operator commented, "Even though this business only breaks even, we continue on because I consider it a marketing arm of our other business." Another operator noted, "Agritourism is primarily for education on herbs. Profits come from [sales of] herbal products produced on the farm."

Agritourism operators' assessments of their profitability increased with
Empire rated profitability as at least a 5 (fairly profitable) (40\%). Conversely, North Coast operations were most likely to rate their profitability as 3 (somewhat profitable) or lower (67\%), followed by the Foothill and Mountain region (62\%). The types of agritourism activities most prevalent in these low-revenue/low-profitability regions should be investigated; these operations appear to have the greatest potential to benefit from consultation regarding business planning and marketing.

Profitability assessments varied widely by primary activity (fig. 5).

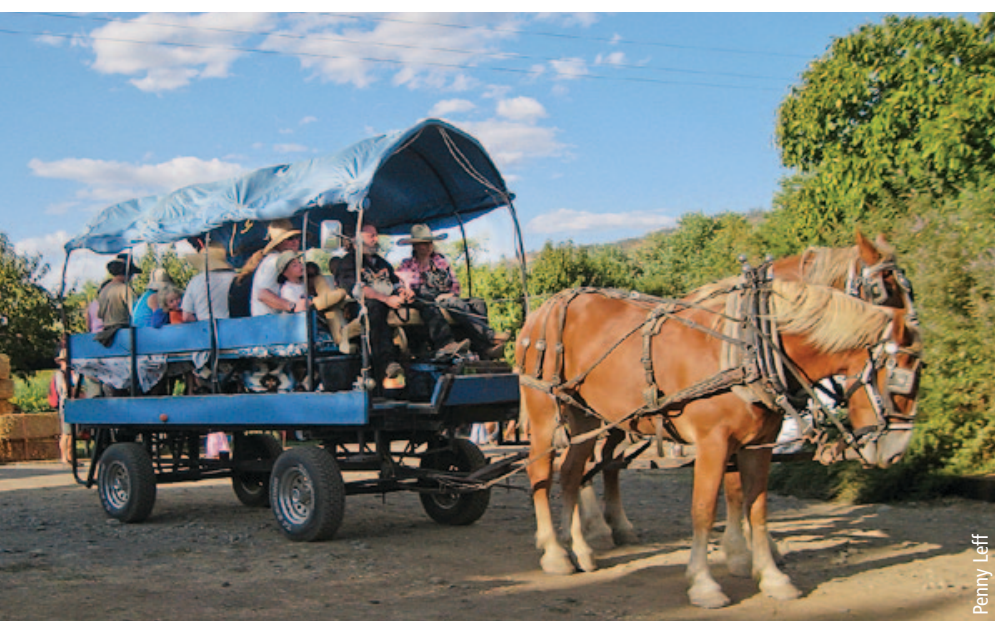

Most agritourism operators said that they like interacting with visitors to their farms. Those surveyed had an estimated total of $\mathbf{2 . 4}$ million visitors in 2008. At Full Belly Farm in Yolo County, visitors tour the farm during the Hoes Down Harvest Festival.
Thirty-two percent of operators rated retail sales of agricultural products, the largest activity category, as at least "fairly profitable," compared to $27 \%$ of operators for whom retail sales were a secondary activity. Retail sales of agricultural products and corn maze/pumpkin patch were the only activities rated more profitable as primary than secondary activities. Those for whom tours and field trips were secondary activities rated their profitability considerably gross revenues, and the differences were statistically significant at the 0.01 level. More than half (53\%) of the operators with agritourism revenues of $\$ 50,000$ or more considered their operations at least "fairly profitable," compared to $15 \%$ with agritourism revenues under $\$ 50,000$.

Respondent assessments of their operation's profitability varied by region, and the differences were statistically significant at the 0.05 level. Similar to gross revenues, a noticeably higher proportion of operators in the Inland higher than those for whom they were primary activities.

\section{Creating jobs and growth}

In general, tourism is considered to have both negative and positive economic impacts. Critics contend that tourism often generates low-paying, seasonal job opportunities; however, if tourism can attract high numbers of seasonal and permanent residents, then it is usually considered to have positive impacts on a community (Reeder and Brown 2005).
Employee numbers and pay. In our survey, agritourism operators reported their employee numbers (excluding themselves) based on categories of hours worked. One-third of the operations had employees who worked at least full time primarily or exclusively for the agritourism operation; a similar proportion had employees who worked between 21 and 39 hours a week. More than half (54\%) of the operations had employees who worked half time or less, primarily or exclusively for the agritourism operation; some of these operations also had full-time employees. Overall, California operations surveyed averaged 6.3 employees (both full- and part-time) hired to work mainly or only for agritourism activities.

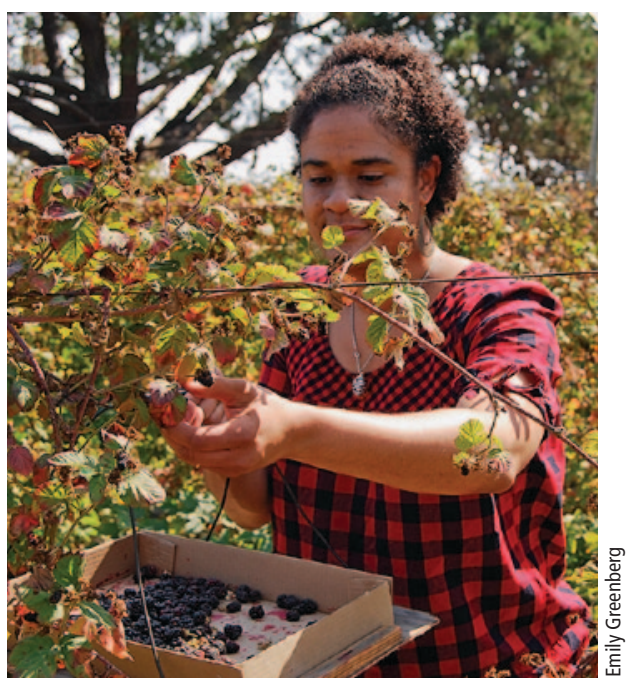

Leah van der Mei, of San Francisco, picks raspberries at Good Humus farm in the Capay Valley, in northwest Yolo County. About 23\% of the farms surveyed offered U-pick. 
In addition, more than half of the operations had employees working mainly for their farming/ranching operation who also pitched in on agritourism activities; on average, there were 2.3 such employees per agritourism operation. Operations with no employees were included in calculating the reported mean values; however, the mean calculation did not include the "missing cases" that occurred frequently because respondents checked a particular employment category but did not indicate the number of employees for that category.

Overall, $83 \%$ of the operations had paid employees, with an average of 11.6 per operation. This value is significantly higher than the sum of the average numbers of employees in the previously discussed categories (hired primarily or exclusively for agritourism activities, or for farming and ranching activities). This disparity is due to the fact that there were many missing cases that occurred when adding together the number of employees for the two categories. Not surprisingly, on average half of all agritourism operations hired one family member, meaning that there were 10.6 nonfamily employees per agritourism operation.

It is not uncommon for agritourism operations to have multiple employees. In our survey, $17 \%$ had no employees and only $5 \%$ had just one employee; but $13 \%$ had more than 10 employees and $8 \%$ had more than 20 employees. (Fortyfive percent of respondents checked a specific employee category but did not report the number of employees.)
In the largest primary-activity category (retail sales of agricultural products) there were 8.4 jobs per operation on average, despite the fact that $32 \%$ of such operations reported no employees. One-fourth of the retail operations had more than 10 employees.

Wages and salaries. Slightly more than half of the operations (53\%) had no employees or paid less than $\$ 5,000$ in employee wages, almost one-fifth (19\%) paid between $\$ 10,000$ and $\$ 49,999$ in salary expenses, and $13 \%$ paid more than $\$ 100,000$ per year (fig. 6).

Since this wage data was categorical, total salary expenses were estimated using the midpoint of each category as the observed value, along with $\$ 1,000$ for the lowest and $\$ 100,000$ for the highest category. This procedure generated average wage expenses of $\$ 24,489$ per agritourism operation, probably a considerable underestimate given the relatively large proportion of operations in the highest wage-expense category.

The economic effects of agritourism are apparent. Even though many of the agritourism operations hired employees at least part time $(83 \%)$, agritourism is adding additional economic activity to rural communities. The average $\$ 24,489$ in wages paid is likely spent within the community and sustains other local businesses.

Growth trends. When asked about their agritourism plans over the next 5 years, the majority of operators (64\%) indicated that they expected to expand or diversify. Almost a quarter (23\%) planned to maintain their current income level. Only $4 \%$ expected to go out of business.

Not surprisingly, growth plans appeared to be correlated with profitability. Seventy percent of the operators who rated their enterprises at least "fairly profitable" planned to expand or diversify, compared to $53 \%$ who rated theirs "not at all profitable" or "slightly profitable."

There were differences across regions regarding growth plans. The highest proportions of operations planning to expand or diversify were in the South Coast, Inland Empire and Central Valley regions (fig. 7A).

There were also differences regarding growth plans among primary activities $(P<0.05)$ (fig. 7B). Events, corn

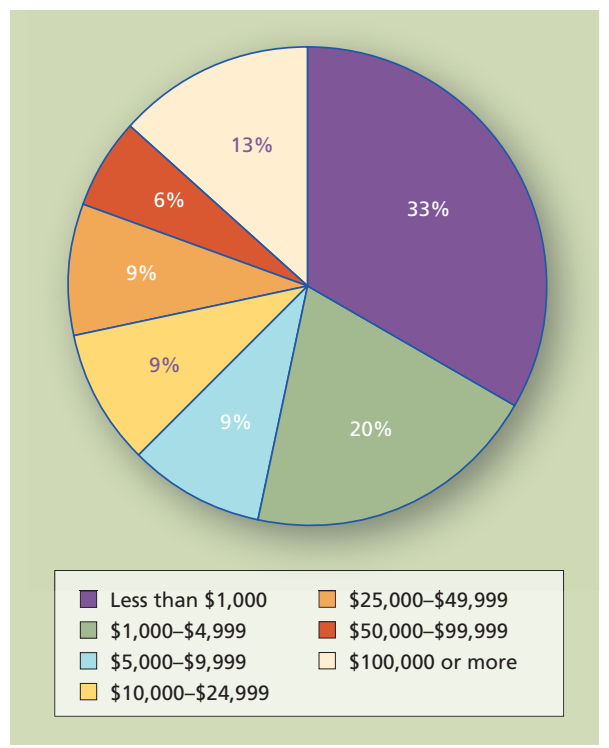

Fig. 6. Range of wages and salary expenses paid by agritourism operations $(n=277)$.
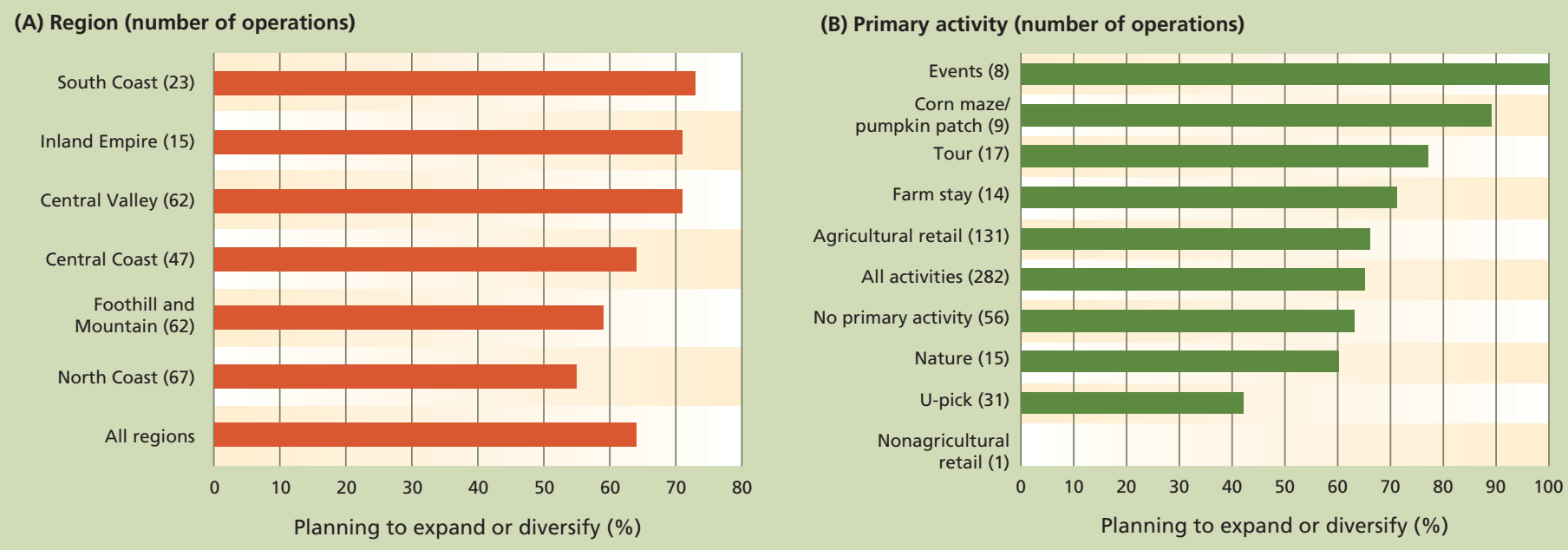

Fig. 7. Survey respondent's growth plans by (A) region and (B) primary activity. 


\section{California counties adapt permitting and regulations for agritourism}

\author{
by Penny Leff
}

$C$ alifornia's 58 counties bear the primary responsibility for permitting and regulating agritourism operations on agricultural land within their boundaries. The counties often struggle with creating allowances and ease of permitting for agritourism businesses while ensuring that agritourism is a supplemental (rather than primary) activity on a commercial farm or ranch. Regulations also must ensure that agricultural production and local residents are not adversely affected by tourism. Some counties have recently changed their general plans, zoning ordinances and staffing assignments to encourage agritourism and have created guides to agritourism permitting.

The Lake County general plan includes Goal AR-3, “To provide opportunities for agritourism that are beneficial to the county and its agricultural industry and are compatible with the long-term viability of agriculture." The countywide general plan in Calaveras

\section{References}

Brown DM, Reeder RJ. 2007. Farm-based Recreation, Statistical Profile. USDA Economic Res Rep 53. Washington, DC.

Bruch M, Holland R. 2004. A Snapshot of Tennessee Agritourism: Results from the 2003 Enterprise Inventory. Univ Tenn Ext Pub PB1747. Knoxville, TN. http:// cpa.utk.edu/pdffiles/PB1747.pdf (accessed Oct. 20, 2009)

Chesnutt TJ. 2007. Developing an Agri-Tourism Attraction in Alabama. Alabama Cooperative Ext Syst, CRD-83. Auburn, AL.

[CTTC] California Travel and Tourism Commission. 2007. Rural Tourism Strategic Plan (2007-13.) Sacramento, CA.

CTTC. 2008. Data Tables. Sources of Travel and Tourism Statistics. http://tourism.visitcalifornia.com/media/ uploads/files/editor/Research/2008_.

George H, Rilla E. 2008. Agritourism Enterprises on your Farm or Ranch: Where to Start. UC ANR Pub 8334. Oakland, CA. 4 p.

German C, et al. 2008. Expanding E-Commerce Opportunities for Farm Fresh Markets and Agri-Tourism Industries. AgMrc Special Projects Initiative. University of Delaware, Department of Food and Resource Economics, College of Agriculture and Natural Resources and Innovative Exchange. Newark, DE. agricultural operation.
County (Foothill and Mountain region) specifically allows, by right, on-site sales and tasting, and directs that the definition of agricultural operations allowed should be broadly construed. Solano County (Central Valley region) has designated new zoning that encourages agritourism in Suisun Valley, one of 10 county regions defined in its general plan.

Mariposa, Placer and El Dorado counties (Foothill and Mountain region) have involved farmers and ranchers on advisory committees that created ordinances to streamline permitting for agritourism operations while limiting the extent of allowed activities in proportion to the size of the primary

Potential agritourism operators often complain about the lack of coordinated information from different county regulatory departments. To address this problem, Marin County (North Coast region) contracts with UC Cooperative

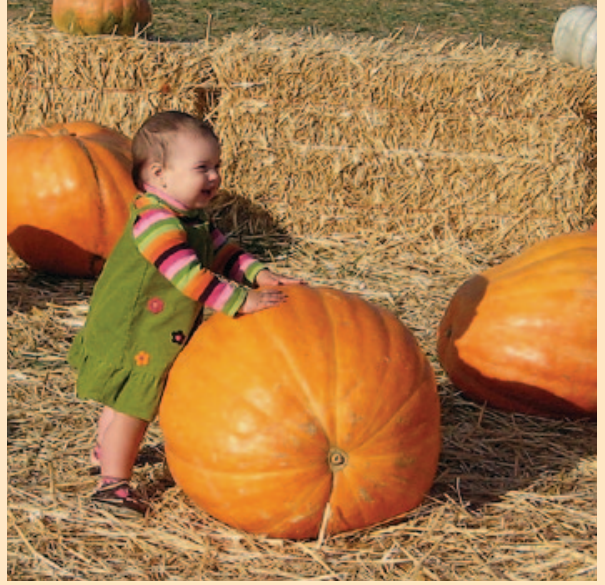

Regulators must strike a balance between promoting agritourism and ensuring that local residents are not adversely affected by traffic and other impacts. Above, a toddler visits Dave's Pumpkin Patch in West Sacramento.

Extension (UCCE) for an "agricultural ombudsman" to assist applicants with agriculture-related permitting. Marin County UCCE and Placer County staff created plain-language guides for farm-stay operations. Yolo County has created an Agricultural Permit Manual that describes all the permits that may be needed for various types of agritourism operations. More coordination among county departments and between counties would ease the regulatory burden on agritourism operators.

P. Leff is Agritourism Coordinator, UC Small Farm Program.
Hilchey D. 1993. Agritourism in New York State: Opportunities and Challenges in Farm-Based Recreation and Hospitality. Farming Alternatives Program, Department of Rural Sociology, Cornell University. Ithaca, NY.

Keith D, Rilla E, George H, et al. 2003. Obstacles in the agritourism regulatory process: Perspectives of operators and officials in ten California counties. AIC Issues Brief 22:1-6.

Klotz J. 2002. How to Direct-Market Farm Products on the Internet. www.ams.usda.gov/AMSv1.0/ getfile?dDocName.

Kuehn D. 2002. New York State's 1999 Agritourism Business Study. Proc 2001 Northeastern Recreation Res Symp, April 1-3, 2001, Bolton Landing, NY. USDA Forest Service Gen Tech Rep NE-289. Northeastern Forest Experiment Station. Radnor, PA.

Leonard J. 2008. Wildlife Watching in the U.S.: The Economic Impacts on National and State Economies in 2006. Addendum to the 2006 National Survey of Fishing, Hunting and Wildlife-Associated Recreation Report, 2006-1. US Fish and Wildlife Service. Arlington, VA.

Mace D. 2005. Factors Motivating Agritourism Entrepreneurs. Kansas State University, Dept of Agricultural Economics. Paper presented at 2005 Risk and Profit Conference, Manhattan, KS, Aug. 11-2. www.ag manager.info/events/risk_profit/2005/Mace.pdf.

Miller M. 2005. Agritourism Profile. lowa State University. www.agmrc.org/commodities_products/ agritourism/agritourism_profile.cfm (accessed Nov. 15, 2010).
Mirus S. 2009. States' Agritourism Statutes. National Agricultural Law Center, University of Arkansas. Fayetteville, AR. www.nationalaglawcenter.org/research. Ollenburg C, Buckley R. 2007. Stated economic and social motivations of farm tourism operators. J Travel Res 45(4):444-52

Reeder RJ, Brown DM. 2005. Recreation, Tourism and Rural Well-Being. USDA Economic Res Rep 7. Washington, DC

Rilla E. 1998. Unique Niches: Agritourism in Great Britain and Selected East Coast States. UC Cooperative Extension. Novato, CA. $68 \mathrm{p}$

Ryan S, DeBord K, McClellan K. 2006. Agritourism in Pennsylvania: An Industry Assessment. Center for Rural Pennsylvania. Harrisburg, PA. www.ruralpa.org/ agritourism2006.pdf (accessed Oct. 20, 2009).

[USDA] US Department of Agriculture. 2004. Agricultural Resource Management Survey. Economic Research Service. Washington, DC.

USDA. 2009. Income From Farm-Related Sources: 2007 State Data. National Agricultural Statistics Service. Washington, DC. www.agmrc.org/ commodities_products/agritourism.

Wine Institute. 2006. Report on Economic Impact of California Wine. MKF Research. San Francisco, CA www.wineinstitute.org. 